\title{
PERANCANGAN SISTEM DETEKSI OBJEK PADA ROBOT KRSBI BERBASIS MINI PC RASPBERRY PI 3
}

\author{
Ilfan Sugianda), Thamrin ${ }^{2)}$ \\ ${ }^{1,2}$ Prodi Pendidikan Teknik Elektronika, Universitas Negeri Padang \\ e-mail : $\underline{{ }^{1} \text { llfanbrt12@,gmail.com, }{ }^{2} \text { thamrin elka@ft.unp.ac.id }}$
}

\begin{abstract}
KRSBI Wheeled is One of the competitions on the Indonesian Robot Contest,. It is a football match that plays 3 robot full autonomous versus other teams. The robot uses a drive in the form of wheels that are controlled in such a way, to be able to do the work the robot uses a camera sensor mounted on the front of the robot, while for movement in the paper author uses 3 omni wheel so the robot can move in all directions to make it easier towards the ball object. For the purposes of image processing and input and output processing the author uses a Single Board Computer Raspberry PI 3 are programmed using the Python programming language with OpenCV image processing library, to optimize the work of Single Board Computer(SBC) Raspberry PI 3 Mini PC assisted by the Microcontroller Arduino Mega 2560. Both devices are connected serially via the USB port. Raspberry PI will process the image data obtained webcam camera input. Next, If the ball object can be detected the object's position coordinates will be encoded in character and sent to the Microcontroller Arduino Mega 2560. Furthermore, Arduino mega 2560 will process data to drive the motors so that can move towards the position of the ball object. Based on the data from the maximum distance test results that can be read by the camera sensor to be able to detect a ball object is \pm 5 meters with a maximum viewing angle of $120^{\circ}$.
\end{abstract}

Keywords: OpenCV, KRSBIberoda,Raspberry PI 3

\section{INTISARI}

KRSBI (Kontes Robot Sepak Bola Indonesia) tipe Beroda merupakan salah satu perlombaan pada Kontes Robot Indonesia . Merupakan suatu pertandingan sepakbola yang dimainkan 3 robot full Autonomous melawan tim lain. Robot menggunakan penggerak berupa roda-roda yang dikontrol sedemikian rupa, untuk dapat melakukan pekerjaan nya robot menggunakan sensor kamera yang terpasang pada bagian depan robot, sedangkan untuk pergerakan pada papers ini penulis menggunakan 3 buah roda omni wheel sehingga robot dapat bergerak kesegala arah untuk memudahkan robot menuju objek bola. Untuk keperluan pengolahan citra dan pemrosesan input dan output penulis menggunakan Single Board Computer Raspberry PI 3 diprogram menggunakan Bahasa pemrograman Python dengan pustaka pengolahan citra OpenCV untuk mengoptimalkan pekerjaannya Single Board Computer Raspberry PI 3 di bantu Mikrokontroler Arduino Mega 2560. Kedua perangkat tersebut terhubung secara serial melalui port usb. Mini PC Raspberry PI akan mengolah data gambar yang didapat dari input kamera webcam. Selanjutnya jika objek bola sudah dapat dideteksi koordinat posisi objek akan dikodekan dalam bentuk karakter dan dikirimkan ke mikrokontroler Arduino Mega 2560, Selanjutnya Arduino mega 2560 akan memproses data untuk menggerakkan motor-motor supaya dapat bergerak menuju posisi objek bola. Berdasarkan data hasil pengujian jarak maksimal yang dapat dibaca oleh sensor kamera untuk dapat mendeteksi objek bola adalah \pm 5 meter dengan sudut pandang pembacaan kamera maksimal $120^{\circ}$.

Kata Kunci : OpenCV, KRSBIberoda, Raspberry PI 3 


\section{PENDAHULUAN}

Kontes Robot Indonesia (KRI) merupakan ajang rancang bangun robotika yang diselenggarakan Kementerian Riset, Teknologi dan Pendidikan Tinggi dengan Kategori yang berbedabeda setiap tahunnya. KRI bertujuan untuk mewadahi mahasiswa dalam bidang robotika sehingga dapat terus berkembang dan dirasakan manfaatnya. KRSBI Beroda (Kontes Robot Sepak Bola Beroda) adalah salah satu kategori baru dalam Kontes Robot Indonesia (KRI), yang mengadopsi pertandingan sepakbola robot yang dipertandingkan di tingkat internasional (RoboCup Middle Size League) diselenggarakan sejak tahun 1997 [6]. Pertandingan robot sepakbola beroda dilakukan pada lapangan indoor dengan ukuran $6 \mathrm{x}$ 9 meter, dan menggunakan bola futsal ukuran no 4 [6]. Pada satu pertandingan di Indonesia masingmasing tim terdiri dari 3 buah robot full autonomous beroda dengan peran yang berbedabeda [6], bertanding melawan tim lain dengan jumlah robot yang sama dan minimal menggunakan 2 robot pada saat pertandingan dan tidak dibenarkan adanya campur tangan manusia pada saat pertandingan berlangsung.

Kontes Robot Sepak Bola Beroda adalah salah satu kompetisi robot tingkat Nasional yang diselenggarakan Belmawa Kemenristekdikti yang mengacu pada aturan pertandingan sepakbola robot Internasional Robocup Middle Size dan merupakan ajang kompetisi antara mahasiswa dari berbagai perguruan Tinggi Se Indonesia. Pada tahun 2017, Tim robotik UNP mulai mengembangkan riset pada robot sepakbola beroda dan menghasilkan robot sepak bola beroda versi pertama dengan tiga roda Omni wheel sebagai penggerak dan Single kamera yang terletak pada bagian depan sebagai sensor utama, Tipe kamera yang digunakan adalah jenis webcam yang berfungsi sebagai sensor utama untuk mendeteksi objek bola. Dengan menggunakan sebuah sensor kamera dapat menggantikan peran dari sensor lainnya, tentunya dengan penerapan algoritma pengolahan citra gambar sehingga citra atau gambar yang berhasil diambil dapat diproses lebih lanjut dan digunakan datanya untuk keperluan tertentu pada pemrosesan dan dapat menggantikan peran dari sebuah sensor, seperti untuk mengukur jarak benda, membedakan bentuk benda berdasarkan tepi objek, warna dan lainnya. Pada paper kamera digunakan sebagai sensor untuk menangkap objek gambar dan berikutnya diolah menggunakan metode pengolahan citra gambar dengan pustaka pengolahan Citra Opencv dan akan diterapkan pada program deteksi objek bola pada robot sepakbola beroda yang berfungsi sebagai sensor utama pada robot sehingga robot dapat mengetahui koordinat posisi objek bola berdasarkan pandangan menggunakan sebuah sensor kamera dan dapat menuju posisi koordinat objek yang terdeteksi.

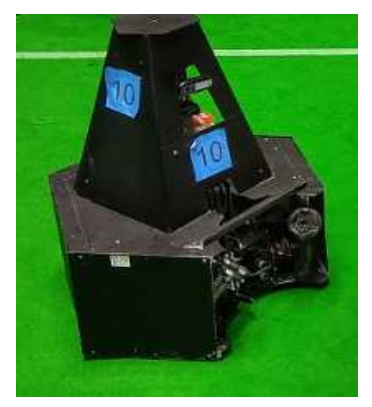

Gambar 1. Robot KRSBI UNP beroda V.1

Penelitian pada paper ini, terfokus pada pembuatan program deteksi objek bola yang akan diterapkan pada robot KRSBI beroda. Program untuk pengolahan citra dirancang dengan Bahasa pemrograman Python dan Library Image Processing OpenCV, Untuk mendukung proses software digunakan hardware Single Board Computer (SBC) Raspberry PI 3 yang dibantu mikrokontroler Arduino Mega 2560 sebagai pengolah data untuk navigasi pada robot sepakbola beroda.

Latar belakang masalah yang mendasari dalam paper perancangan sistem deteksi objek bola pada robot KRSBI Beroda yaitu : menentukan Metode pengolahan citra yang tepat serta settingan parameter yang tepat untuk diterapkan pada robot KRSBI beroda, serta melakukan pengujian kemampuan jarak deteksi objek bola oleh robot, dan memaksimalkan fungsi Hardware Single Board Computer (SBC) raspberry PI 3 sebagai Prosesor utama untuk pengolah data citra bergerak yang diambil oleh kamera webcam.

Tujuan perancangan dan penerapan perancangan program software deteksi objek bola menggunakan Single Board Computer(SBC) Raspberry PI 3 yaitu untuk merancang sebuah robot KRSBI beroda yang memiliki kemampuan tracking objek bola secara realtime dan bisa mengetahui koordinat objek bola berdasarkan arah pandangan kamera serta mengklasifikasikan nya dalam bentuk warna dan menandai koordinat posisi objek yang terdeteksi.

\section{PENDEKATAN PEMECAHAN MASALAH Pengolahan Citra (Image Processing)}

Pengolahan citra atau (Image Processing) adalah "proses untuk memperbaiki kualitas citra, khususnya menggunakan komputer menjadi citra 
yang kualitasnya lebih baik agar lebih mudah untuk diterjemahkan manusia ataupun mesin" [10]. Sedangkan pengolahan citra digital adalah "Pemrosesan gambar berdimensi-dua melalui komputer" [3].

Pada pengolahan citra banyak fungsi yang dapat digunakan salah satunya adalah pengenalan pola, kontur, warna dan lainnya. Salah satu contoh penerapannya yaitu pada beberapa bidang keilmuan seperti bidang penginderaan jauh, Machine Vision atau Computer Vision (Sistem yang dapat "melihat" dan "memahami" yang dilihatnya), dan diterapkan pada berbagai aspek lainnya pengolahan citra berperan untuk mengenali bentuk bentuk-bentuk khusus yang dapat dilihat oleh komputer sehingga bentuk tersebut dapat diinterpretasikan dalam bentuk lainnya yang dapat menggantikan peran dari sebuah sensor. Beberapa metode pengolahan citra bergerak akan dicoba diterapkan pada robot KRSBI Beroda dengan bantuan pustaka Open $C V$.

\section{OpenCV}

OpenCV adalah singkatan dari Open Source Computer Vision Library, Merupakan sebuah pustaka perangkat lunak pengolahan citra yang dirancang untuk efisiensi komputasi dengan focus yang kuat pada aplikasi pengolahan citra secara realtime[4]. Karena OpenCV sifatnya yang Open Source dapat digunakan dan didownload secara bebas pada website resminya : www.opencv.org untuk penggunaan akademis dan komersial. OpenCV memiliki antarmuka program $\mathrm{C}++$, Python dan java serta dapat dijalankan pada sistem operasi Linux, Windows, Mac OS, iOS dan Android. Pustaka library OpenCV ditulis dengan Bahasa pemrograman $\mathrm{C}$ dan $\mathrm{C}++$.

Pada website resminya OpenCV tersedia banyak sumber belajar yang dapat digunakan oleh para pemula yang ingin mempelajari mengenai pengolahan citra, terdapat beberapa metode serta dokumentasi program dan tutorial hingga proses aritmatika pengolahan citra pada dokumentasi onlinenya. Pada penelitian ini penulis menggunakan pustaka OpenCV sebagai software untuk mengolah citra yang diprogram menggunakan Bahasa pemrograman python dan dijalan pada sebuah perangkat keras Mini PC raspberry PI 3 dengan sistem Operasi Raspbian (Raspberry Debian). Pada gambar 2 merupakan gambar logo perusahaan OpenCV.

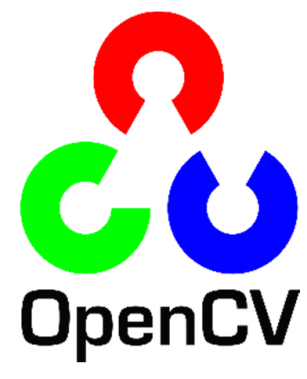

Gambar 2. Logo OpenCV[4]

\section{Morfologi pada Pengolahan Citra}

Operasi morfologi adalah salah satu operasi pengolahan citra yang umum digunakan untuk pengolahan citra digital khususnya citra biner(hitam-putih)[3]. Dengan menggunakan operasi morfologi pada pengolahan citra struktur citra biner yang sudah disegmentasi dapat diperbaiki ataupun dikurangi noisenya. Operasi yang mendasari Morfologi yaitu erosi dan dilasi serta bentuk variannya seperti Opening dan Closing. Untuk lebih jelasnya mengenai operasi morfologi berikut ini dijabarkan berdasarkan contoh Coding serta perubahannya berikut ini :

\section{Erosi}

Erosi adalah operasi morfologi yang memperbaiki citra biner melalui pengikisan tepi citra [4]. Tepi pada citra biner yang melalui operasi morfologi erosi akan dikikis sehingga dapat mengurangi noise pada sisi tepi citra biner. Berikut ini contoh program morfologi erosi menggunakan pustaka OpenCV dengan Bahasa pemrograman Python :
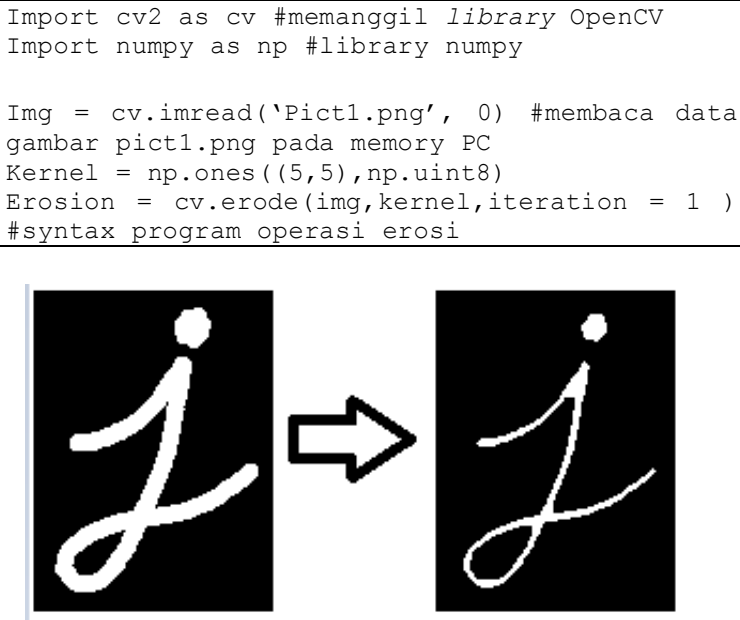

Gambar 3. Operasi morfologi erosi [4]

Pada gambar 3 dapat dilihat perubahan pada citra setelah sebelumnya dilakukan proses 
morfologi erosi, citra yang disekelilingnya piksel bawahnya 0 (hitam) akan diubah menjadi 0 dan sebaliknya jika piksel sekelilingnya 1 maka piksel akan tetap bernilai 1 (putih).

\section{Dilasi}

Merupakan kebalikan dari operasi morfologi erosi [4], operasi morfologi dilasi akan melakukan efek pelebaran pada piksel bernilai 1 sehingga operasi dapat memperbaiki citra biner dan menggabungkan bagian-bagian yang rusak pada suatu objek. Berikut ini contoh gambar hasil operasi morfologi dilasi.

Syntax program[4]:

Dilation =
cv.dilate (img, kernel, iterations=1)
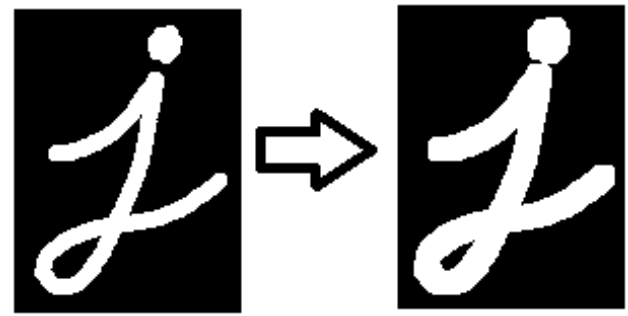

Gambar 4. Operasi Morfologi dilasi [4]

\section{Opening}

Operasi morfologi opening merupakan penggabungan antara operasi morfologi Erosi yang diikuti setelahnya oleh operasi morfologi Dilasi. Operasi ini berfungsi untuk menghilangkan noise pada objek [4]. Untuk menggunakan operasi morfologi Opening dengan pustaka OpenCV cukup dengan memanggil fungsi cv.morphologyEx(). Berikut ini hasil dan contoh syntax pada program menggunakan python.

Syntax program[4]:

\begin{tabular}{|l}
\hline $\begin{array}{l}\text { Opening } \\
\text { kernel) }\end{array}$ \\
\hline
\end{tabular}
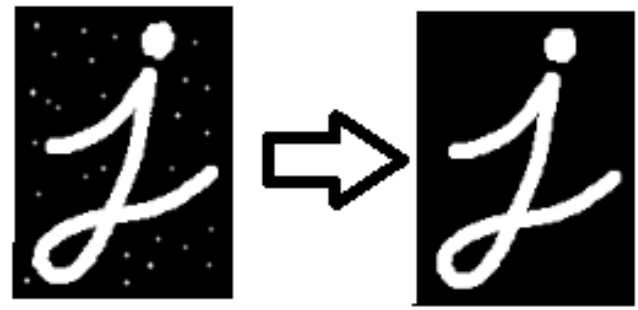

Gambar 5. Operasi morfologi opening [4]

\section{Closing}

Operasi Morfologi closing merupakan kebalikan dari operasi morfologi opening [4]. Pada operasi morfologi closing dilakukan proses dilasi terlebih dahulu dan diikuti proses morfologi erosi. Operasi Closing akan menghilangkan noise yang terdapat pada citra dengan piksel 1 seperti pada contoh berikut ini :

\section{Syntax program [4]:}

Closing = cv.morphologyEx(img,PCV.MORPH_CLOSE,
kernel)
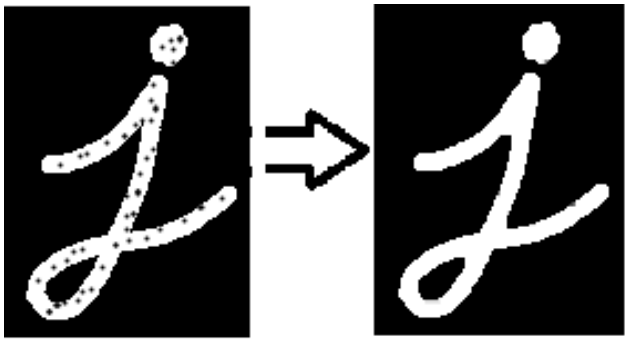

Gambar 6. Operasi morfologi Closing [4]

\section{Model Warna HSV}

Model warna HSV (Hue, Saturation, Value) adalah satu bentuk representasi warna alternatif dari warna RGB(Red, Green, blue). Model warna HSV pertama kali diperkenalkan oleh A.R. Smith pada tahun 1978 [1]. Seperti ditunjukkan pada gambar 7.

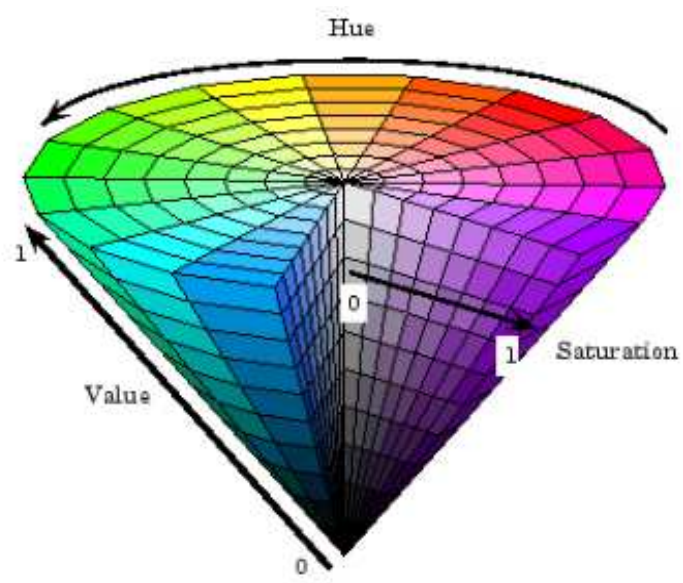

Gambar 7. Model warna HSV [1].

Berdasarkan ilustrasi pada gambar 7 dapat dilihat Hue adalah sudut dari $0^{\circ}$ sampai dengan $360^{\circ}$. Pada gambar dapat dilihat pada sudut $0^{\circ}$ adalah warna merah, sudut $60^{\circ}$ warna kuning, sudut $120^{\circ}$ warna hijau, sudut $180^{\circ}$ warna cyan, sudut $40^{\circ}$ warna biru, sudut $300^{\circ}$ warna magenta. Hue menyatakan warna sebenarnya seperti : merah, kuning, Cyan, Magenta, dan juga digunakan 
menentukan kemerahan (Redness), kehijauan (Greenes), dan lainnya. Saturation adalah kemurnian atau kekuatan warna. Sedangkan Value adalah kecerahan warna nilainya berkisaran 0-100 $\%$ apabila nilainya 0 maka warnanya akan menjadi hitam, semakin besar nilainya maka warna semakin cerah.

Pada program deteksi objek dilakukan penyaringan warna HSV sebelumnya akan ditetapkan nilai range batasan warna yang ingin dideteksi dalam bentuk bilangan dengan model warna RGB lalu warna yang berhasil dideteksi tersebut diubah ke bentuk HSV dan selanjutnya dijadikan citra biner (hitam-putih) untuk diolah pada proses berikutnya pada operasi morfologi.

\section{Raspberry PI 3}

Merupakan salah satu jenis Single Board Computer atau Mini PC yang sudah umum digunakan pada bidang-bidang tertentu. Raspberry PI 3 model B merupakan model pertama dari generasi ke 3 yang dikeluarkan Raspberry PI foundation, Raspberry PI 2 Model B yang dirilis pada Februari 2016[5] merupakan generasi sebelumnya. Berikut ini adalah spesifikasi lengkap dari perangkat keras Raspberry PI 3 Model B [5] pada gambar 8 dan 9 :

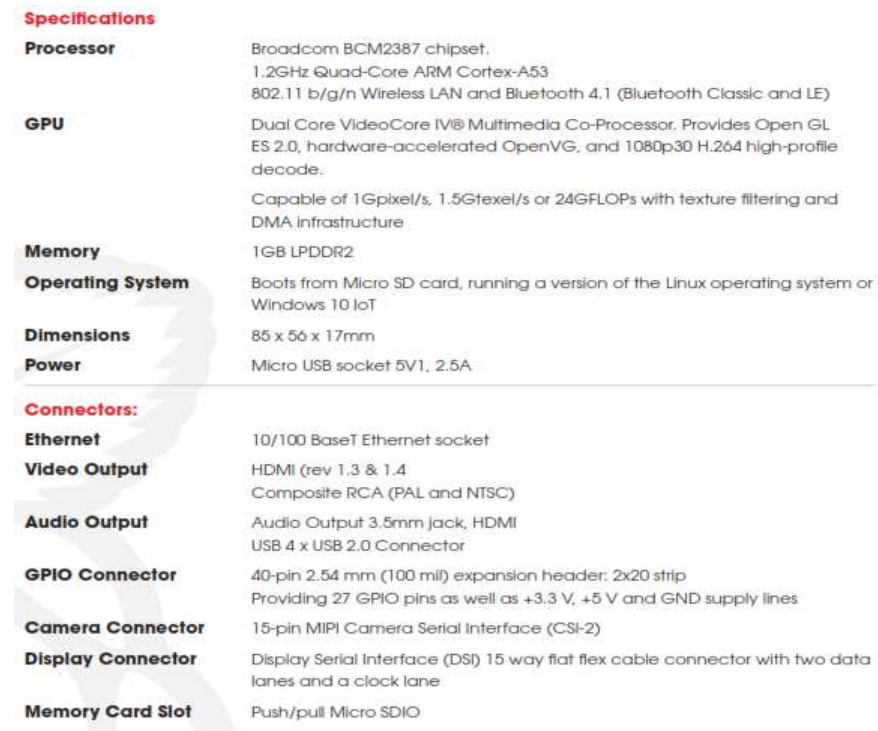

Gambar 8. Spesifikasi Raspberry PI 3 [7]

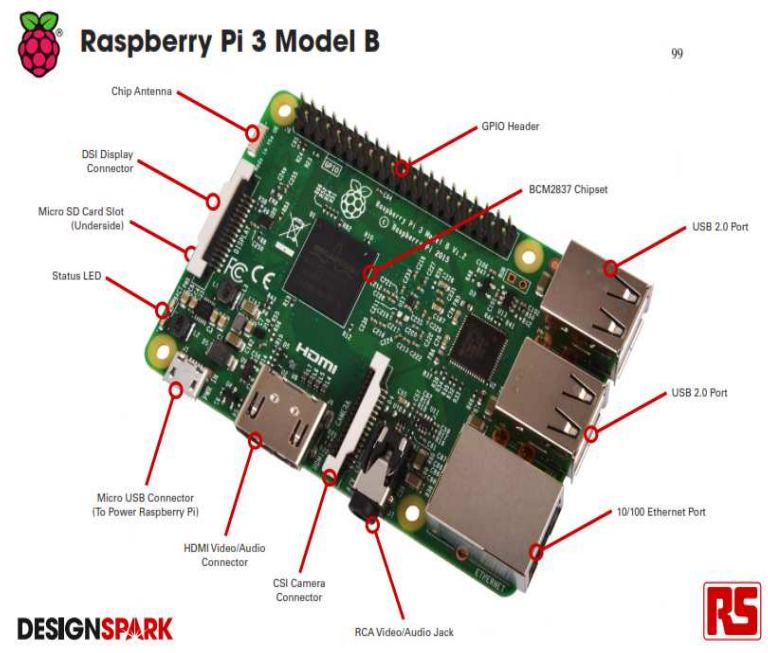

Gambar 9. Board Raspberry PI 3 [7] 


\section{Blok Diagram Sistem Robot Secara Keseluruhan}

Perancangan Sistem secara keseluruhan Digambarkan pada blok diagram berikut ini :

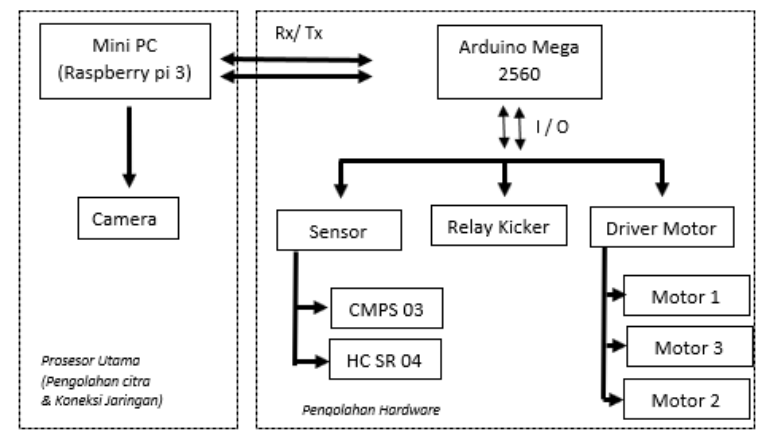

Gambar 10. Diagram Blok Sistem Robot Secara Keseluruhan

Pada Gambar 10 menjelaskan mengenai proses kerja sistem secara keseluruhan serta keterkaitan antara bagian perangkat keras pengolahan citra bergerak seperti kamera webcam ,mini komputer dengan komponen pendukung yang digunakan pada robot.Pada gambar 10 di atas juga dapat dilihat pembagian tugas masing-masing komponen antara lain: Single Board Computer(SBC) Raspberry PI 3 berfungsi sebagai mikroprosesor utama untuk pemrosesan citra gambar mikrokontroler Arduino Mega 2560 berfungsi sebagai mikrokontroler yang melakukan pengolahan pergerakan robot dan mengolah data dari beberapa sensor pada yang terhubung pada perangkat Arduino Mega 2560. Mini PC Raspberry PI 3 terhubung pada perangkat Arduino Mega 2560 melalui jalur komunikasi Serial $(R x / R x)$, Mini PC Raspberry PI 3 akan mengolah data Objek yang berhasil ditangkap melalui kamera webcam, Selanjutnya data tersebut akan diolah sehingga didapatkan koordinat objek bola yang berhasil dideteksi, data koordinat yang didapat tersebut akan dikodekan dalam bentuk kode ASCII yang dikirimkan ke mikrokontroler Arduino melalui jalur komunikasi Serial.

\section{Diagram Alir Program Pengolahan Citra}

Rancangan program sistem deteksi objek bola yang diterapkan pada robot KRSBI beroda menggunakan metode Colour Filtering HSV sedangkan urutan proses diagram alir program dapat dilihat pada Gambar 11.

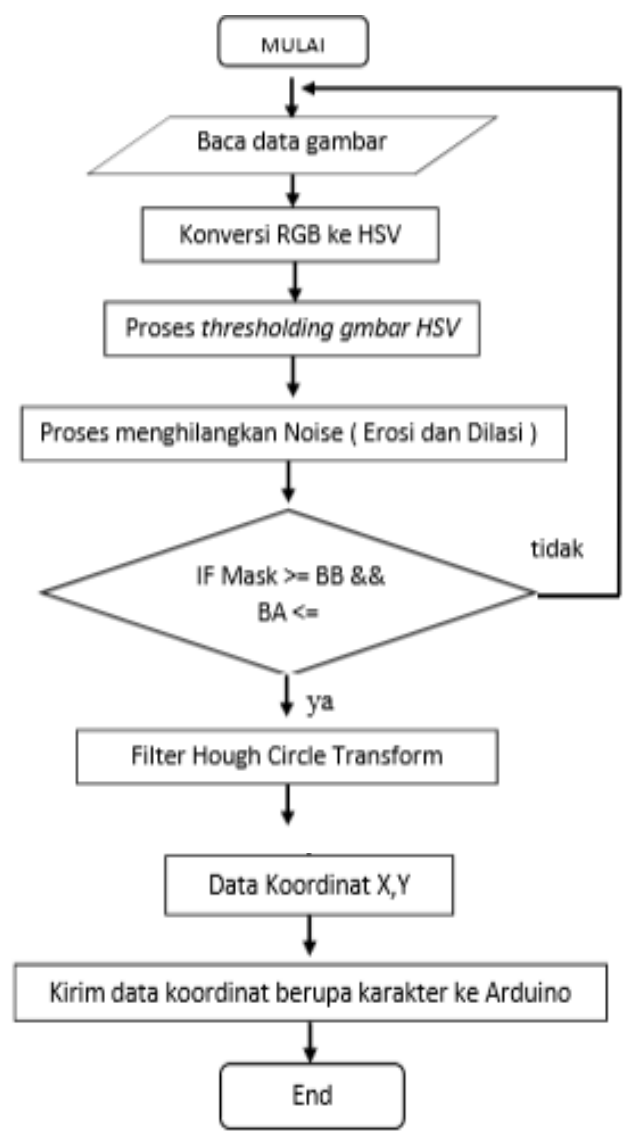

\section{Gambar 11. Diagram Alir Program Pengolahan Citra Pada Robot}

Pada diagram Alir program gambar 11 menampilkan urutan proses program pengolahan citra gambar pada software.Tahapan awal yang dilakukan adalah inisialisasi kamera webcam, pada tahapan ini kamera webcam akan memulai proses pengambilan citra gambar.Urutan berikutnya setelah itu nilai batasan angka warna yang akan dideteksi oleh robot yang telah ditetapkan sebelumnya dalam bentuk model warna $R G B$ akan membaca warna sesuai kode yang sudah ditetapkan lalu kamera hanya akan mendeteksi objek berdasarkan warna yang sudah ditetapkan dan model $R G B$ tersebut, lalu diubah dalam bentuk model $H S V$ dan setelahnya dilakukan proses thresholding untuk menjadikan citra yang didapat menjadi citra biner. 


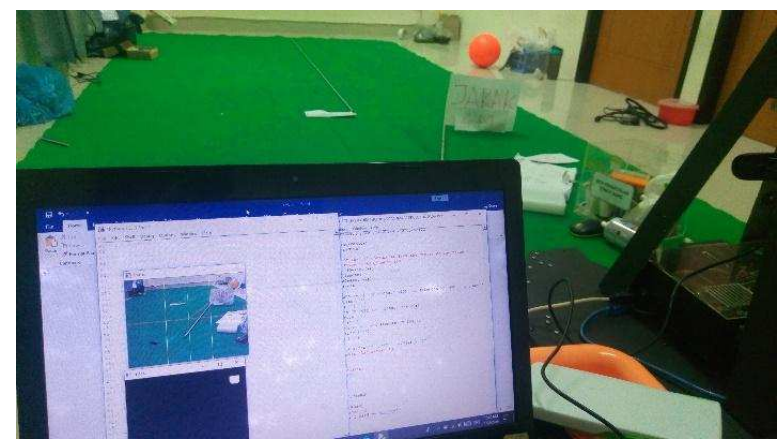

Gambar 12. Proses pengambilan objek gambar pada robot ditampilkan pada layar komputer

Citra hasil filter $R G B$ to $H S V$ yang memfilter objek gambar berdasarkan warna akan menjadikan citra menjadi citra biner sehingga dapat diolah pada OpenCV lebih lanjut, akan tetapi karena terdapat noise pada citra hasil pembacaan kamera diperlukan sebuah operasi yang dapat mengurangi noise pada citra biner (Hitam-putih). Operasi tersebut adalah operasi morfologi Opening dan Closing, kedua operasi tersebut merupakan penggabungan operasi dilasi dan erosi yang bertujuan untuk memperbaiki kualitas citra biner sehingga citra biner tersebut dapat diolah lebih lanjut pada program.

Proses selanjutnya adalah mendeteksi objek menggunakan fungsi contours detection yaitu deteksi objek berdasarkan bentuk citra biner hasil dari operasi morfologi opening dan Closing. Sehingga objek gambar yang sudah diolah sebelumnya dapat dipastikan lagi dari bentuk contours objek tersebut dan didapatkan titik pusat koordinat objek.Jika objek gambar dalam sebuah frame video sudah terdeteksi,lalu akan dilanjutkan ke tahapan selanjutnya yaitu mengambil data koordinat posisi objek yang terdeteksi dengan bantuan pustaka OpenCV. Koordinat posisi objek ditentukan melalui titik pusat objek yang berhasil dideteksi. Nilai koordinat digambarkan pada sumbu $x$ dan $y$ yaitu berdasarkan arah pandangan robot. Titik 0,0 berada pada posisi center padangan robot. Untuk efektifitas pergerakan robot penulis membagi frame layar berdasarkan beberapa kuadran, lalu jika objek dideteksi pada kuadrankuadran tertentu maka datanya akan dikodekan dengan kode ASCII lalu kode tersebut dikirimkan pada mikrokontroler Arduino Mega 2560, dan datanya diproses untuk navigasi robot menuju objek dengan cepat. Jika tidak ada objek yang terdeteksi maka juga akan dikirim kode ASCII ke mikrokontroler Arduino lalu robot akan melakukan Scanning objek bola dengan cara berputar perlahan sampai dengan $360^{\circ}$ dan begitu seterusnya sampai ada objek yang berhasil dideteksi robot pada lapangan pengujian.

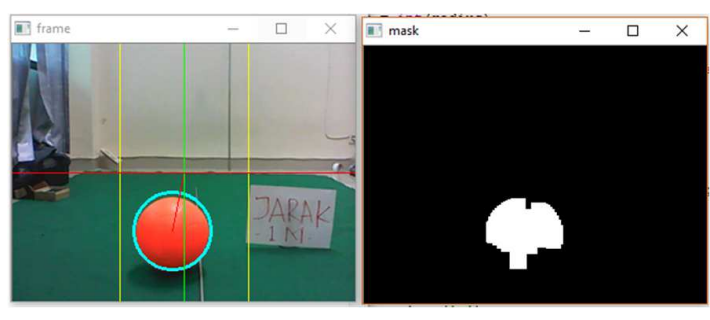

Gambar 13.Tampilan Objek bola yang berhasil dideteksi robot

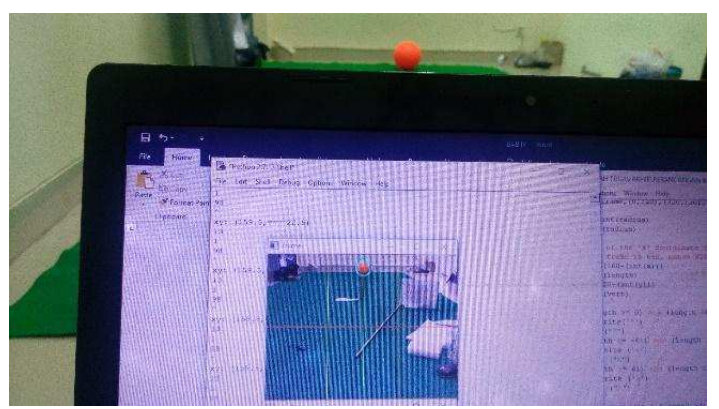

Gambar 14.Tampilan nilai koordinat posisi objek pada python shell

Pada tampilan Gambar 13 ditampilkan objek bola yang berhasil dikenali oleh robot, pada gambar juga diperlihatkan bentuk citra biner(Hitam putih) yang merupakan proses akhir dari hasil urutan seperti yang dijelaskan pada diagram alir Gambar 11. pengolahan citra hasil dari operasi morfologi Opening dan closing dapat dilihat dengan baik bekerja pada gambar ini karena hamper tidak ada noise pada objek yang dideteksi robot sehingga objek bola dapat dikenali dengan baik oleh robot. Pada gambar 14 ditampilkan hasil data koordinat posisi objek berupa angka pada terminal python shell.

\section{HASIL DAN PEMBAHASAN}

Untuk dapat mengetahui apakah program yang sudah dirancang dapat bekerja dengan maksimal serta untuk mendapatkan data jarak maksimal objek bola yang dapat dideteksi oleh sensor kamera webcam dilakukan pengujian. Pengujian dilakukan dengan cara mengarahkan posisi robot sesuai layout pengujian robot pada gambar 12, lalu bola diletakkan pada beberapa posisi dan jarak tertentu misalkan pada sudut $120^{\circ}$ dengan jarak 2 meter dari posisi robot dan seterusnya. Data hasil pengujian program deteksi objek bola menggunakan metode Colour Filter $H S V$ dengan Library OpenCV ditampilkan pada tabel 1 . 


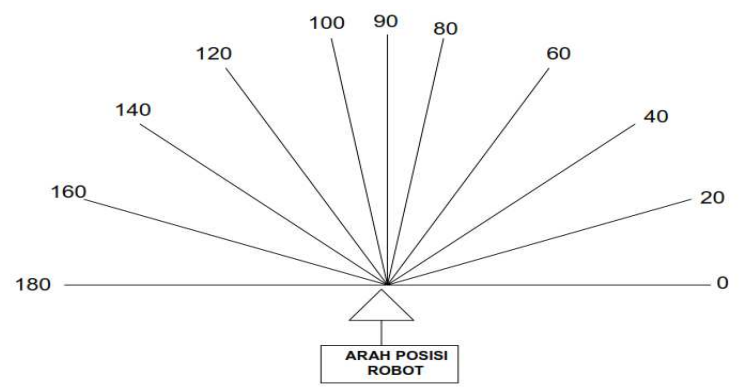

Gambar 15. Layout pengujian robot

Robot diposisikan sesuai dengan gambar kerja pada layout pengujian robot, arah posisi robot disesuaikan dengan peletakan sensor kamera pada robot sehingga robot diposisikan dapat melihat dengan sudut pandang $180^{\circ}$ mengarah pada objek bola. Berikut nya dilakukan beberapa percobaan dengan data hasil pengujian pada tabel 1 .

\begin{tabular}{ccccc}
\multicolumn{3}{l}{ Tabel } & 1. Hasil pengujian sistem deteksi objek \\
\hline No & $\begin{array}{l}\text { Jarak } \\
\text { Objek } \\
\text { dengan } \\
\text { robot }\end{array}$ & Hasil & Gambar hasil deteksi \\
\hline 1 & $\begin{array}{l}1 \text { meter }> \\
80^{\circ}\end{array}$ & Terdeteksi & & \\
\hline
\end{tabular}

$2 \quad 2$ Meter $>$ Terdeteksi $80^{\circ}$

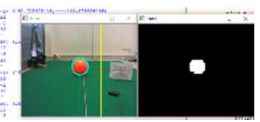

32 meter $>$ Tidak $0^{\circ} \quad$ terdeteksi

43 meter Terdeteksi $>40^{\circ}$
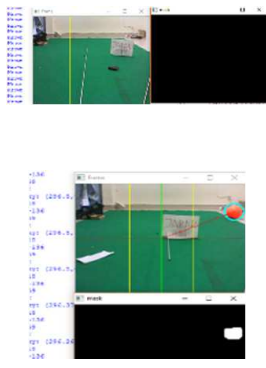

54 meter $>$ Terdeteksi $120^{\circ}$

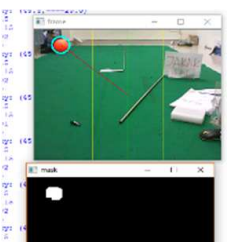

75 meter $>$ Terdeteksi $0^{\circ}$

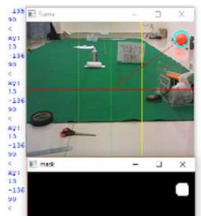

$8 \quad 5$ meter $>\quad$ Terdeteksi $120^{\circ}$

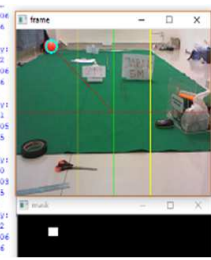

96 meter $>$ Terdeteksi/ $80^{\circ} \quad$ Tidak

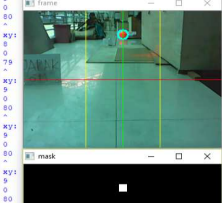

107 meter $>$ Tidak $80^{\circ} \quad$ Terdeteksi

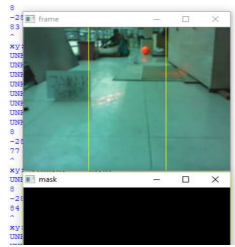

Berdasarkan data yang ditampilkan pada Tabel 1, robot mampu mendeteksi objek dengan jarak maksimal 6 meter akan tetapi pembacaannya lebih baik pada jarak maksimal 5 meter pada saat objek diposisikan pada jarak $>6$ meter pembacaan objek bola tidak begitu baik dan sulit untuk dideteksi oleh robot. Dari data pengujian juga didapatkan sudut maksimal pembacaan objek bola oleh kamera yaitu pada pada sudut $0^{\circ}$ sampai $120^{\circ}$. Pada beberapa percobaan hasil pengujian didapatkan data berupa hasil pembacaan objek bola berdasarkan jarak dan sudut pandang robot dan didapatkan hasil berupa objek terdeteksi dan tidak terdeteksi. Berdasarkan hasil pengujian ada beberapa faktor yang mempengaruhi pembacaan objek tersebut antara lain :

64 meter $>$ Terdeteksi $40^{\circ}$ 
1. Kondisi pencahayaan lingkungan pengujian

2. Kemampuan jarak pembacaan gambar kamera webcam Logitech C-170, kualitas gambar serta viewing angle lensa kamera

3. Kecepatan pemrosesan gambar oleh mikroprosesor

\section{KESIMPULAN}

1. Berdasarkan Hasil pengujian dapat ditarik kesimpulan jarak objek maksimal dengan robot yang dapat dideteksi dengan baik yaitu dengan jarak \pm 5 meter dengan selang waktu tracking (robot menuju posisi bola) berbeda-beda sesuai dengan settingan parameter kecepatan tracking robot menuju objek yang disesuaikan dengan kemampuan pembacaan kamera,jika pembacaan kamera baik,maka kecepatan bisa ditingkatkan dan begitu sebaliknya.

2. Metode yang diimplementasikan pada pada pengolahan citra untuk deteksi objek bola menggunakan metode template matching dengan Colour Filtering HSV objek dideteksi berdasarkan nilai range warna yang sudah ditetapkan sebelumnya dan akan dicocokkan dengan nilai warna objek yang akan dideteksi. Setelah itu, objek yang sudah ditandai berdasarkan warna diubah menjadi citra biner untuk diperbaiki dan menghilangkan noise menggunakan operasi morfologi ketika hasilnya sudah baik objek akan dideteksi berdasarkan kontur dan didapatkan titik pusat objek sehingga posisi koordinat objek didapatkan.

3. Pada pembacaan kamera layar dibagi atas beberapa kuadran sehingga koordinat objek pada kuadran-kuadran tertentu akan dikodekan dalam kode ASCII dan dikirimkan ke mikrokontroler sehingga robot dapat menuju objek yang dideteksi dengan cepat.

\section{DAFTAR PUSTAKA}

[1] Abd Fauzan. Ruang warna HSV. 2019. Website : http://www.charisfauzan.net/. diakses 18 februari 2019.

[2] Al Rasyid, M., Firdaus, \& Derisma. Rancang Bangun Robot Pengering Lantai Otomatis Menggunakan Metode Fuzzy. jsiskom JURNAL SISTEM KOMPUTER, 6(3), pp. 63, 2016.

[3] Anggry Yulio P. Operasi morfologi pada pengolahan citra. 2018. Website: https://devtrik.com/opencv/operasimorfologi-pada-pengolahan-citra/. diakses 13 November 2018.
[4] Anonim. OpenCV. 2018. Website: https://opencv.org, diakses 25 November 2018.

[5] Anonim. Raspberry pi. 2018. Website: https://www.raspberrypi.org, diakses 25 oktober 2018.

[6] Anonim. Panduan KRSBI Beroda. 2019. Website: https://kontesrobotindonesia.id/kri-2019. diakses 14 Januari 2019.

[7] Datasheet Raspberry PI 3 www.rscomponents.com/ raspberrypi.

[8] Endra Pitowarno. Robotika ( Desain, Kontrol, dan Kecerdasan Buatan ). Yogyakarta : Penerbit Andi. 2006.

[9] Hendriko, Irwan, \& Nugraha,LM. I. Penerapan Color Filtering HSV untuk pendeteksi Bola pada Robot KRSBI Beroda. The 6th Indonesian Symposium on Robotic System and Control (ISRC), (hlm.21). yogyakarta. 2018.

[10] Kadir, A., \& Adhi, S. Teori dan Aplikasi Pengolahan Citra. Yogyakarta: Penerbit ANDI. 2013.

[11] Kadir, Abdul. Dasar Raspberry Pi. Yogyakarta : Penerbit ANDI. 2017.

[12] Monika Deswal, Neetu Sharma, "A Fast HSV Image Color and Texture Detection and Image Conversion Algorithm", International Journal of Science and Research (IJSR), 2012.

[13] Sanjaya WS, M. Robot Cerdas berbasis Speech Recognition Menggunakan Matlab dan Arduino. Yogyakarta : Penerbit ANDI. 2016.

[14] Susanto, A., Mulyanti, Prayogo, A.,Susanto, \& Hendryli, J. Rancangan Robot Humanoid 2018. Yogyakarta : the $6^{\text {th }}$ Indonesian Symposium on Robotic Systems and Control (ISRSC). (pp. 176-179). 2018.

[15] Technical data NXP Semikonduktor MC33886 